\section{Publishing, medical students and two pinches of inspiration: the recipe for}

\section{success}

\section{DOI: 10.52629/jamsa.v9i1.202}

Medicine is a competitive field, where postgraduate and residency programs are scarce and highly demanded. A key element taken into consideration for admission to these programs is the number of papers the applicant has published.' Although nowadays many students are involved in research projects, few publish in scholarly journals. ${ }^{2}$

For instance, a recent article explored the status of the teaching methodology and medical student research statistics in a South Indian medical institute. ${ }^{3}$ A central finding was that medical students considered that innovative teaching methods and discussions should be an important part of the teaching methodology. Furthermore, students felt that research and clinical skills training should also be implemented during their medical formation. Nonetheless, $75 \%$ of the surveyed students believed that there was not enough guidance or encouragement to conduct research. Consequently, the student's publishing rate was also low. This is a worrying situation that demands a coordinated response from both students and teachers.

From a medical student's viewpoint, doing research and publishing are exciting but time-consuming processes. A strategy to help palliate this dissonance would be to encourage students to publish the written components or extended academic assignments that they produce for some curricular subjects (Figure 1). ${ }^{4}$ This could range from the documentation of classroom activities to more thoroughly elaborated reviews of basic or clinical topics.

For instance, the authors of the present letter had the chance to collaborate in a systematic review about iron deficiency anemia. ${ }^{5}$ It started as a final assignment and was, after an exciting editorial process, accepted for publication. We believe these types of experiences are valuable since they
José Manuel GonzálezRayas ${ }^{1}$

${ }^{7}$ School of Medicine and Health Science Tecnologico de Monterrey

\section{Correspondence to:}

José Manuel González-Rayas

School of Medicine and

Health Science Tecnologico de Monterrey

contact.jmgr@gmail.com 
encourage the student to directly apply what they have learned in class. Moreover, publishing is a powerful strategy to teach abilities that are not part of traditional research courses, such as communicating with the editors and answering the reviewers. ${ }^{4}$ Medical teachers should also actively encourage their students to do research and publish, since writing an article demands careful consideration of the previously published literature, which is a central step in the practice of evidence-based medicine.

A helpful recommendation would be to work alongside local scientific journals or student journals since they often seek the so-called 'back to the basics' articles. These are mini-reviews of molecular, physiological, or clinical topics, and represent a potential opportunity for students to publish. Furthermore, students should attempt to publish in both English and their native language, since this increases the audience for their work. ${ }^{6-10}$

\section{Evidence supporting publications by medical students in academic journals}

There is a substantial body of evidence supporting the publications authored by medical students. In general, medical students are motivated to conduct research and publish. Nonetheless, two of the biggest barriers they face are lack of time and scarce support from their professors/supervisors. Motivating students to publishing the written components they present for their curricular subjects would be an appropriate strategy to counteract these two barriers. Table 1 summarizes a small sample of the arguments favoring the benefits of student-led publications.

Summing up, publishing is a unique experience that both ensures the achievement of significant learning and strengthens the student's curriculum. It is the job of medical teachers to apply this new approach, and others like it, to help students transform into the health professionals and researchers our society deserves.

\section{Conflicts of interest}

None.

\section{Acknowledgments}

None. 
10 G. Rayas: Publishing, medical students and two pinches of inspiration: the recipe for success

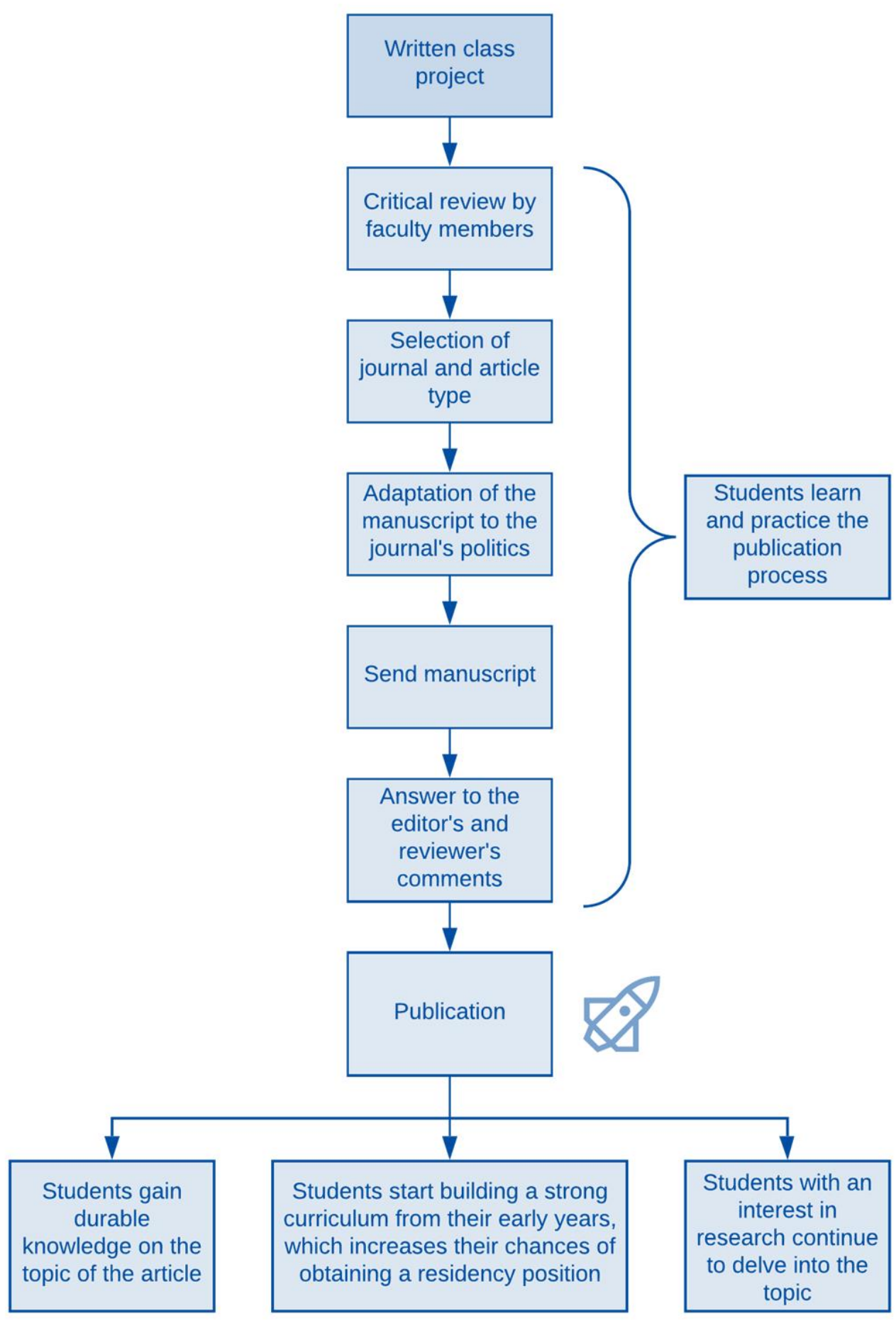

Figure 7 Flowchart depicting the path from the elaboration of a written class project/assignment to publication. 
Table 1. Evidence supporting student-led publications ${ }^{18}$.

\begin{tabular}{llc}
\hline Evidence & Country & Reference \\
\hline $\begin{array}{l}\text { 64.6\% of the students of the University of Panama have } \\
\text { participated in research projects, but only 2.9\% have } \\
\text { published a research article. The main constraint was a lack } \\
\text { of time to develop their research projects. }\end{array}$ & Panama & Ortega-Loubon et al. $^{2}$ \\
\end{tabular}

Students who published on the New Zealand Medical New Zealand Al-Busaidi et al."11 Student Journal had a higher probability of contributing to PubMed-indexed journals (prior and after graduation), obtaining a Ph.D. or any other higher degree, or securing an academic position.

From a cohort of 515 British medical students, only 72 had submitted an article for publication. The student's biggest motivation to publish was for career progression (51\%). Also, $21 \%$ of the participants had an interest in conducting research. Nonetheless, the biggest constraints the students face are lack of opportunity (55\%) and lack of time (16\%).

$52 \%$ of the students included developed one or more of the fundamental skills for research (methods, information gathering, critical analysis and review, and data processing) by conducting a project as part of their undergraduate medical training. "Undergraduates recognize the benefits of research experience but need a realistic understanding of the research process."

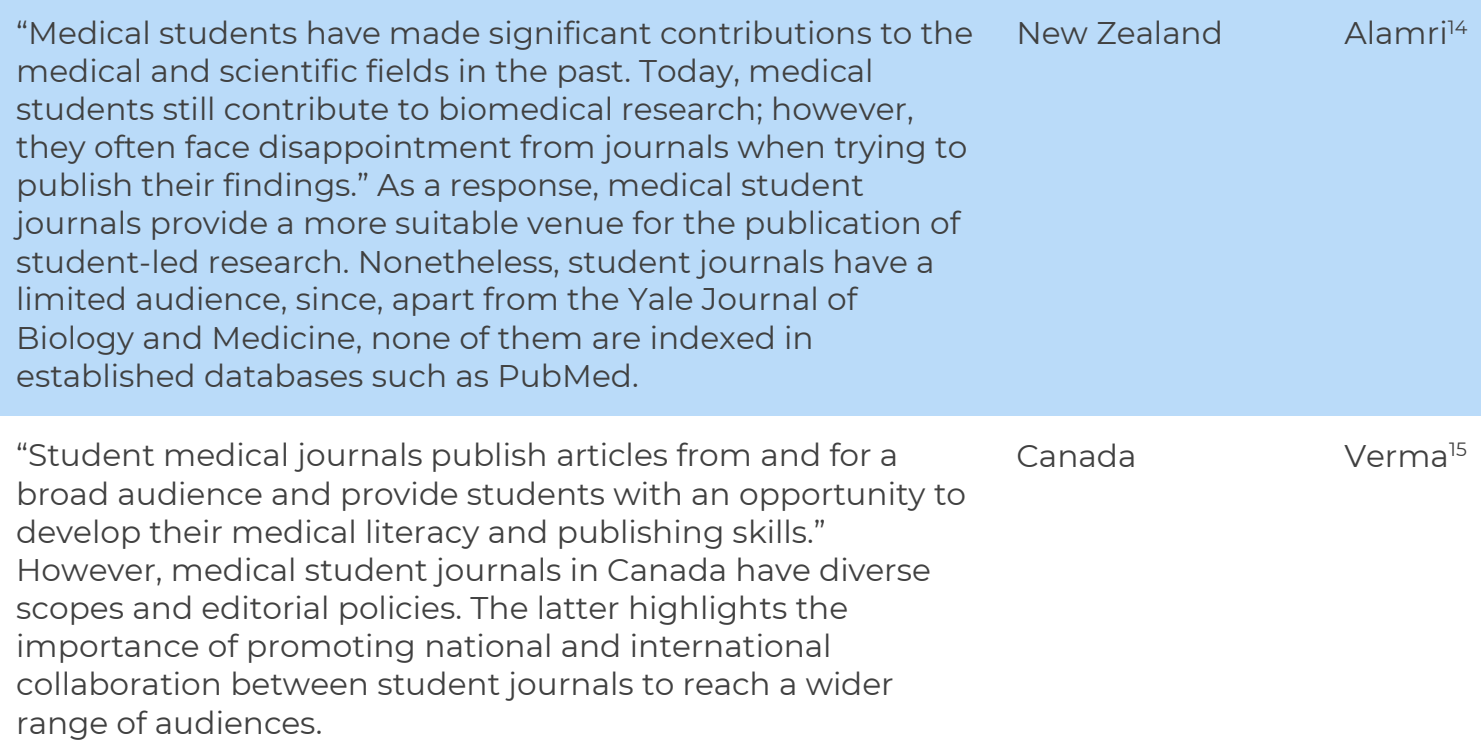

"Student medical journals publish articles from and for a broad audience and provide students with an opportunity to develop their medical literacy and publishing skills." However, medical student journals in Canada have diverse scopes and editorial policies. The latter highlights the importance of promoting national and international collaboration between student journals to reach a wider range of audiences. 


\section{References}

1. Torrie PAG, Berstock JR, Hayward EBS, Bannister GC. Publish or perish - How to avoid perishing. Medical Teacher. 2013 Mar;35(3):260-260

2. Ortega-Loubon C, Zúñiga-Cisneros J, Yau A, Castro F, Barría- Castro J-M, Lalyre A, et al. Producción científica de los estudiantes de medicina de la Universidad de Panamá. Archivos de Medicina. 2013;9(3):1-9.

3. Nekkanti S, Manjunath S, Mahtani A, Meka A, Rao T. A Survey Based Feedback Analysis of the Current Medical Teaching Methodology and Trends in Medical Research Practice in a South Indian Medical Institute. IJMS. 2018 Apr 29;6(1):6-14.

4. González-Rayas JM, López-Sánchez R del C, Rayas-Gómez AL. La publicación como estrategia de aprendizaje significativo en estudiantes de ciencias de la salud: Un caso de éxito. In: Memorias Congreso Internacional de Innovación Educativa 2019 [Internet]. 2019 [cited 2020 Jun 16]. p. 4. Available from: https://ciie.itesm.mx/en/memorias/

5. González Rayas JM, Henne Palomeras LK, Bermúdez Sáyago S, Siller García P, Hornedo Torres V, López Sánchez R del C. Anemia ferropénica en mujeres jóvenes: actividad en el aula y revisión de la literatura con base en dos casos. rev.crit. 2019;6(1):81-108.

6. Di Bitetti MS, Ferreras JA. Publish (in English) or perish: The effect on citation rate of using languages other than English in scientific publications. Ambio. 2017 Feb;46(1):121-7.

7. González-Rayas JM, Rayas-Gómez AL, González-Yáñez JM, García-González JJ, Hernández-Hernández JA, López-Sánchez RDC. The new normal of medical research: replicability and reproducibility. Rev Biomed. 2020 Sep;31(3):108-10. Available from:

http://revistabiomedica.mx/index.php/revbi revb/article/view/840
8. González-Rayas JM, Rayas-Gómez AL, González-Yáñez JM, García-González JJ, Hernández-Hernández JA, López-Sánchez RDC. La nueva normalidad en la investigación médica: replicabilidad y reproducibilidad. Rev Biomed. 2020 Sep;31(3):108-10. Available from: http://revistabiomedica.mx/index.php/revbi revb/article/view/840

9. Landa-Alvarado PD, Rayas-Gómez AL, González-Rayas JM, González-Yáñez JM. Signet Ring Cell Carcinoma Finding after Thoracentesis: When a Routine Procedure Reveals Something Else. ejgg. $2020 \mathrm{Jul}$ 29;2(2):58-9.

10. González-Rayas JM, Rayas-Gómez AL, García-González JJ, González-Yáñez JM, Hernández-Hernández JA, López-Sánchez R del C. COVID-19 and ACE -inhibitors and angiotensin receptor blockers-: The need to differentiate between early infection and acute lung injury. Revista Colombiana de Cardiología. 2020 May;27(3):129-31.

11. Al-Busaidi IS, Wells $\mathrm{Cl}$, Wilkinson TJ. Publication in a medical student journal predicts short- and long-term academic success: a matched-cohort study. BMC Med Educ. 2019 Dec;19(1):271.

12. Griffin MF, Hindocha S. Publication practices of medical students at British medical schools: Experience, attitudes and barriers to publish. Medical Teacher. 2011 Jan;33(1):e18.

13. Murdoch-Eaton D, Drewery $S$, Elton $S$, Emmerson C, Marshall M, Smith JA, et al. What Do Medical Students Understand By Research And Research Skills? Identifying Research Opportunities Within Undergraduate Projects. Medical Teacher. 2010 Jan;32(3):e152-60.

14. Alamri Y. How do medical student journals fare? A global survey of journals run by medical students. Educ Health. 2016;29(2):136. 
15. Verma P, Tso D, Youssef D, Wu D. Canadian Medical-Student Journals: An Overview. Science Editor. 2011;34(4):e5-9. 